Portsmouth, UK

Cite this as: BMJ 2021;374:n1912 http://dx.doi.org/10.1136/bmj.n1912

Published: 05 August 2021

\title{
Why Cuba developed its own covid vaccine-and what happened next
}

\begin{abstract}
While the rest of Latin America set its hopes on buying as many foreign vaccines as possible to turn the tide of coronavirus infections, Cuba, not for the first time in its history, opted to go it alone. Luke Taylor reports
\end{abstract}

\section{Luke Taylor freelance journalist}

Rather than negotiating with pharmaceutical giants or the Covax vaccine sharing initiative, Cuba bet everything on its prestigious biotech sector coming up with its own vaccine against covid-19. And though the gamble has been shrouded in mystery and met with scepticism, it could be paying off.

The island's national regulatory agency approved the Abdala vaccine on $9 \mathrm{July}$, making Cuba the first Latin American country to develop a successful covid-19 vaccine. The Center for State Control of Medicines, Equipment and Medical Devices reports that Abdala is $92 \%$ efficacious after three doses. ${ }^{1}$

Moreover, three other vaccine candidates are still in the pipeline, including Soberana 2, which the agency says is $91 \%$ effective when combined with a booster vaccine called Soberana Plus. Those too are expected to receive regulatory approval in the coming weeks. ${ }^{2}$

And with the worst food and medicine shortages since the collapse of the Soviet Union sparking mass protests, it would not be a moment too soon.

"What a tremendous drive to keep fighting for life!" tweeted President Miguel Díaz-Canel Bermúdez following the announcement of the vaccines' efficacy. "Thanks to our scientists for propping up our hope." 3

\section{Tetris}

Cuba's vaccine breakthrough is the second time that it has been a Latin American outlier during the pandemic. For periods of 2020, while the surrounding region recorded more covid-19 deaths per million population than any other, the island remained almost free of infection. Only 11863 infections and 146 deaths were recorded in its ageing 11 million population-equivalent to 13 deaths per million people. The UK recorded 1084 deaths per million for the same period. ${ }^{4}$

Cuba's success has been attributed to its aggressive testing, tracing, and isolating (Tetris) programme, spearheaded by doctors. Cuba has more physicians per head than anywhere else in the world and dispatched 2000 of them abroad to stabilise collapsing hospitals in countries like Italy. ${ }^{5}$

But the army of healthcare professionals also played a vital role at home. Doctors, nurses, and medical students were sent door to door, advising the public on coronavirus symptoms and searching for possible infections. Those with confirmed coronavirus infections were sent to state run isolation centres to cut transmission chains.
This system was not enough to keep the virus at bay once Cuba reopened its borders in November 2020, however. New infections and variants imported through airports-first gamma and now delta-were too much to control, the World Health Organization's representative in Cuba, Jose Moya Medina, tells The $B M J$.

About 400 ooo cases have now been recorded, with around 9000 more being registered each day. ${ }^{6}$

People with confirmed infections are now monitored at home rather than in isolation centres because of the scale of the epidemic. And the country's economic collapse is making it increasingly hard for people to stay indoors, says Amilcar Perez-Riverol, a former researcher at Cuba's Centre for Genetic Engineering and Biotechnologies, which developed the Abdala vaccine.

"Everything that was working in 2020 now isn't working very well, or not at all, and then you add to that the delta variant," Perez-Riverol says. "It's out of control."

\section{Vaccines to the rescue?}

To stem the spike in cases, Cuba began rolling out its two most promising vaccine candidates on 12 May, despite neither having been approved by the country's regulatory body for emergency use. ${ }^{7}$

Nevertheless, Cuba's most vulnerable 1.9 million people, including healthcare workers and older people, have now been vaccinated as part of what the country labelled an "intervention study."

About $21 \%$ of Cubans have been fully vaccinated (it takes at least two months for the three doses to be administered)-above the regional average but short of the national target of vaccinating $70 \%$ of Cubans by August because of shortages of the Soberana vaccine and the wait for regulatory approval. ${ }^{8}$

When that target is reached, Cuba is likely to become the first country to immunise its entire population with its own vaccines. It would also be the first to roll out a conjugate vaccine for SARS-CoV-2-one that combines a weak antigen with a strong antigen to boost immune response. In the case of Soberana 2, the protein from the virus's receptor binding domain, or spike, is combined with a tetanus toxoid. ${ }^{9}$

All of Cuba's vaccine candidates-Abdala, Soberana 1, Soberana 2, Soberana Plus, and Mambisa, are subunit protein vaccines, like the Novavax vaccine. Crucially, the vaccines do not require extreme 
refrigeration, are cheap to produce, and are easy for the country to manufacture at scale. They are made by fermentation in mammalian cells, a process Cuba already uses for monoclonal antibodies.

\section{Vaccine diplomacy}

Cuba plans to share its vaccines with the rest of the region, much of which continues to face vaccine shortages and large outbreaks. Argentina, Mexico, and Jamaica are among those discussing potential deals, ${ }^{10}$ as is Vietnam. Iran has just started mass producing Soberana 2 after running phase III clinical trials in January. ${ }^{17}$

Cuba's state managed biotech sector has a long history of producing successful vaccines. ${ }^{11}$ It was backed heavily by Fidel Castro, who pumped at least a billion dollars into the sector, starting in the 1980s, to make health a core principle of his socialist project and to bring much needed foreign currency into the country through exports. ${ }^{12}$ The country manufactures eight of the 11 vaccines used in its national immunisation programme, which has eliminated polio, diphtheria, measles, rubella, and whooping cough. ${ }^{13}$ It also exports hundreds of millions of vaccines a year, including the world's first meningitis B vaccine, ${ }^{18}$ to more than 40 countries. ${ }^{14}$

But prestige alone will not convince the rest of the world's scientists, who remain sceptical of the tiny, cash strapped communist nation's capabilities, says Perez-Riverol. "Cuba needs to address its biggest criticism: that clinical trial results have not been published in a scientific journal," he says.

Although Venezuela became the first foreign nation to receive Cuban vaccines on 24 June, there was little take-up and plenty of hesitancy despite other covid-19 vaccines being scarce. ${ }^{15}$

Medicos Unidos, a group of Venezuelan healthcare workers monitoring the country's health crisis, opposes the use of Cuban vaccines until peer reviewed studies of phase III trials are published or they gain WHO approval.

The Pan American Health Organisation (PAHO) is pressing Cuba's government to make its data public in scientific journals; this would allow it to distribute them through the Covax scheme to other low and middle income countries.

"I think it's very important that the producers of the Abdala vaccine-if they have finished all three phases of clinical trials - publish the data in a transparent way so that the scientific community can also evaluate this information," PAHO's assistant director, Jarbas Barbosa, told a media briefing.

The BMJ asked BioCubaFarma, which oversees Cuba's health research and development, if and when it would publish clinical trial data, but it did not respond.

Vaccines could be a way out of not just the public health crisis but the economic and political crises threatening the island nation. Cubans are accustomed to financial hardship and scarcity, but inflation has soared and supermarket shelves have become increasingly bare in the past year.

Discontent with widespread food, medicine, and vaccine shortages has boiled over. The protests seen in the week of 12 July were the largest in Cuba's recent history and were met with a government crackdown, with hundreds of protesters arrested. PAHO has expressed concern that the discontent could exacerbate outbreaks. ${ }^{16}$

"The surge in covid infections in Cuba has now become a source of popular discontent, so the government's ability to quickly vaccinate the public has political as well as public health implications," says William Leogrande, Cuba specialist and professor of government at American University in Washington, DC.
"If the Cuban vaccines work as advertised and the government can distribute them quickly enough to get the pandemic under control again, it will relieve one source of the public's frustration."

Competing interests: I have read and understood the BMJ policy on declaration of interests and have no relevant interests to declare.

Provenance and peer review: Commissioned; not externally peer reviewed.

Cuba says Abdala vaccine 92.28\% effective against coronavirus. Reuters 2021 Jun 22. https://www.reuters.com/business/healthcare-pharmaceuticals/cuba-says-abdala-vaccine-9228 effective-against-coronavirus-2021-06-21/

2 Cuba says second COVID-19 vaccine Soberana 2 boasts 91.2\% efficacy. Reuters 2021 Jul 19. https://www.reuters.com/business/healthcare-pharmaceuticals/cuba-says-second-covid-vaccinesoberana-2-boasts-912-efficacy-2021-07-09/

3 Diaz-Canel Bermudez M. Tweet, 9 Jul 2021. https://twitter.com/DiazCanelB/status/1413449699311243265?s=20

4 Our World in Data. Total confirmed COVID-19 deaths and cases per million people, 31 Dec 2020. https://ourworldindata.org/grapher/total-covid-cases-deaths-per-million?tab=map\&time=2020 12-31\&country= OWID_WRL

5 How doctors became Cuba's biggest export. Time2018 Nov 30. https://time.com/5467742/cubadoctors-export-brazil/

6 Our World in Data. Cumulative confirmed covid-19 cases. 29 Jul 2021. https://ourworldindata.org/explorers/coronavirus-data-explorer?zoomToSelection=true\&hideControls=true\&Metric $=$ Confirmed+cases\&Interval=Cumulative\&Relative+to+Population=false\&Align+outbreaks=false\&country=IND USA GBR CAN DEU FRA

7 Inyección de Cuba genera esperanzas en el inicio de la vacunación masiva por COVID-19. Reuters 2021 May 12 https://www.reuters.com/article/salud-coronavirus-cuba-idESKBN2CT2RU

8 El 70\% de la población cubana estará vacunada en agosto. Granma 2021 May 8. http://www.granma.cu/cuba-covid-19/2021-05-08/el-70-de-la-poblacion-cubana-estara-vacunadaen-agosto-08-05-2021-01-05-21

9 Ramirez Gonzalez M. COVID-19 vaccine made in Cuba. [Rapid response to: Mwananyanda et al. Covid-19 deaths in Africa: prospective systematic postmortem surveillance study]. BMJ 2021. https://www.bmj.com/content/372/bmj.n334/rr

10 Cuba says Abdala vaccine $92.28 \%$ effective against coronavirus. Reuters 2021 June 22. https://www.reuters.com/business/healthcare-pharmaceuticals/cuba-says-abdala-vaccine-9228effective-against-coronavirus-2021-06-21/

11 Cuba says Iran to start producing one of its COVID-19 vaccines. Reuters 2021 Jul 29. https://www.reuters.com/business/healthcare-pharmaceuticals/cuba-says-iran-start-producingone-its-covid-19-vaccines-2021-07-29/

12 PAHO. Cuba. Health in the Americas. 2012. https://www3.paho.org/salud-en-las-americas2012/index.php?option=com_docman\&view=download\&category_slug=hia-2012-countrychapters-22\&alias=125-cuba-125\&ltemid=125\&lang=en

13 Cuba's advances in biotech: a developing country with a highly developed biotech sector. IHS Markit 2012. https://ihsmarkit.com/research-analysis/cubas-advances-in-biotech-a-developingcountry-with-a-highly-developed-biotech-sector.html

14 Reed G, Galindo MA. Cuba's national immunization program. MEDICC Rev 2007;9:5-7.pmid: 21487351

15 Americas Cuba vaccine deal breaks embargo. BBC News 1999 Jul 29. http://news.bbc.co.uk/1/hi/world/americas/406780.stm

16 Cuba leads race for Latin American coronavirus vaccine. Reuters 2020 Nov 12. https://www.reuters.com/article/uk-health-coronavirus-vaccine-cuba-focus-idUKKBN27S10Z

17 Despite ally donations, few Venezuelans get COVID-19 vaccine. Independent 2021 Jul 2. https://www.independent.co.uk/news/despite-ally-donations-few-venezuelans-get-covid19vaccine-nicolas-maduro-covid-caracas-cuban-havana-b1877443.html

18 Cuban protests risk exacerbating covid-19 spike-PAHO. Reuters 2021 Jul 14 https://www.reuters.com/world/americas/cuban-protests-risk-exacerbating-covid-19-spike-paho2021-07-14/

This article is made freely available for use in accordance with BMJ's website terms and conditions for the duration of the covid-19 pandemic or until otherwise determined by BMJ. You may use, download and print the article for any lawful, non-commercial purpose (including text and data mining) provided that all copyright notices and trade marks are retained. 